\title{
Metal-free synthesis of biarenes via photoextrusion in di(tri)aryl phosphates
}

\author{
Hisham Qrareya ${ }^{1,2}$, Lorenzo Meazza ${ }^{1}$, Stefano Protti ${ }^{1}$ and Maurizio Fagnoni ${ }^{* 1}$
}

\section{Full Research Paper}

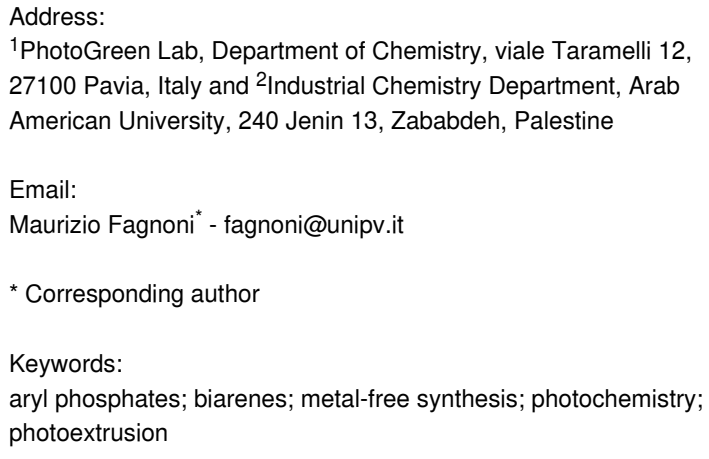

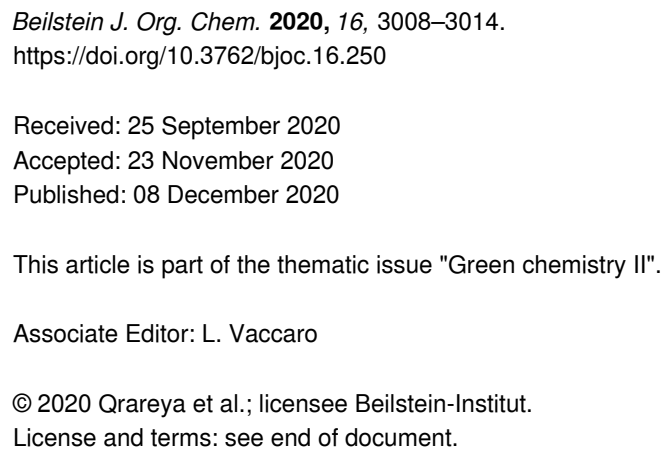

\begin{abstract}
A metal-free route for the synthesis of biarenes has been developed. The approach is based on the photoextrusion of a phosphate moiety occurring upon irradiation of biaryl- and triaryl phosphates. The reaction involves an exciplex as the intermediate and it is especially suitable for the preparation of electron-rich biarenes.
\end{abstract}

\section{Introduction}

It is difficult to overestimate the importance of aromatics in drug development. Indeed, introducing an aromatic or a heteroaromatic ring, most often a (substituted) phenyl ring, into a biologically active compound is a common practice in medicinal chemistry [1-3]. In particular, the biaryl moiety is a privileged scaffold largely present in the skeleton of natural substances [4-7] and in useful chiral ligands [8-10]. The synthesis of biaryl derivatives remains, however, a considerable challenge [11-13]. Common methods, such as the Ullmann and Gomberg synthesis [14-16] have been nowadays supplanted by the much more versatile metal-catalyzed cross-coupling reactions [17-23]. This excellent approach still encounters some limitation in the scope and in the practical application, due to the use of labile and expensive reagents. Moreover, the elimina- tion of metal trace residues and wastes is of some concern particularly for products destined to pharmaceutical applications as it is imperative operating under 'green' conditions. As for the last issue, there is nowadays a growing interest in the forging of Ar-Ar bonds under transition-metal-free conditions [24,25]. Apart the most common pathways, e.g., the Friedel-Crafts functionalization [26] or nucleophilic aromatic substitution [27], alternative approaches have emerged that make use of photogenerated intermediates (triplet aryl cations [28,29] or aryl radicals $[30,31])$. As for the former case, the intermolecular formation of a biaryl arose from the photoheterolysis of an Ar-N bond (in arene diazonium salts or their derivatives [32,33]), of an $\mathrm{Ar}-\mathrm{Cl}$ bond [34,35], of an Ar-O bond (in aryl phosphates [36], aryl sulfonates [36], and in aryl trifluoroethyl sulfate [37], 
Scheme 1a) followed by the reaction of the thus formed aryl cation with an aromatic substrate. In an alternative approach, aryl radicals may be generated under photoredox catalysis conditions (mostly from arene diazonium salts or aryl iodides) [30,31] or by the direct photolysis of arylazo sulfones [38-40] and employed for the desired arylations. These reactions have the advantage of being applied to non-functionalized arenes but have the drawback to require a large excess of the nucleophilic reagent (the arene $\mathrm{Ar}-\mathrm{H}$ ) in up to 10-20-fold amount. Furthermore, the aryl radical/cation addition onto the aromatic reactant

a)

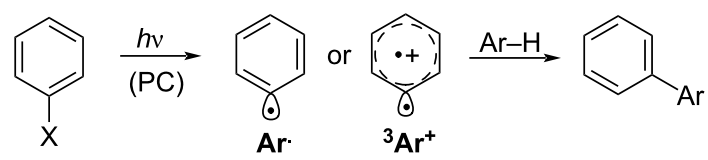
$\mathrm{X}=\mathrm{N}_{2}{ }^{+}$, halogen, $\mathrm{OSO}_{2} \mathrm{R}, \mathrm{OP}(\mathrm{O})(\mathrm{OEt})_{2}, \mathrm{OSO}_{2} \mathrm{OCH}_{2} \mathrm{CF}_{3}$, $\mathrm{N}_{2} \mathrm{SO}_{2} \mathrm{Me}$

b)<smiles>[Y]c1ccccc1-c1ccccc1</smiles>
$\mathrm{X}=\mathrm{NMe}, \mathrm{O}, \mathrm{CH}_{2}$<smiles>[Y]C(=O)O[Na]</smiles>

d)

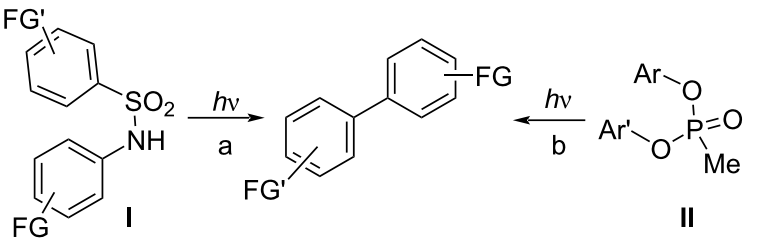

e) this work<smiles>N=[PH](=O)(Oc1ccccc1)Oc1ccccc1OP(=O)(O)c1ccc(F)cc1</smiles>

III, $W=O E t$

IV $\mathrm{W}=\mathrm{OPh}$

Scheme 1: Synthesis of biarenes via a) photogenerated triplet aryl cations and aryl radicals ( $\mathrm{PC}=$ photocatalyst), b) intramolecular free radical ipso substitution, c) thermally catalyzed extrusion of $\mathrm{CO}$ and $\mathrm{SO}_{2}$, d) photoinduced photoextrusion from benzene sulfonamides I and phosphonates II, and e) photoextrusion from diaryl- (III) and triaryl (IV) phosphates. may lead to a mixture of regioisomers when using non-symmetrical $\mathrm{Ar}-\mathrm{H}$. A possible solution is having recourse to an intramolecular free radical ipso substitution reaction where an $\mathrm{XSO}_{2}$ tether is placed between two aromatic rings to direct the selective $\mathrm{Ar}-\mathrm{Ar}$ bond formation (Scheme 1b) [41-43]). In this case, $N$-methyl sulfonamides were the elective substrates albeit a part of the tether is maintained in the final structure. This is common even for other related metal-free biaryl syntheses exploiting the Truce-Smiles rearrangement in aryl sulfonamides and aryl phenylsulfonates [44-46] or the [3,3]-sigmatropic rearrangement of sulfonium salts arising from the reaction of aryl sulfoxides and phenols [47]. To overcome this problem, the use of a metal catalyst (mainly $\mathrm{Ni}$ ) was mandatory as reported for the real extrusion of $\mathrm{CO}$ in diaryl ketones $[48,49]$ or of $\mathrm{SO}_{2}$ in diaryl sulfones (Scheme 1c) [50]. Nevertheless, a recent publication demonstrated that a metal-free photoextrusion was feasible when starting from benzene sulfonamides I (Scheme 1d, path a) [51]. Following the same approach, sparse reports described that in some cases biaryls may be obtained in variable yields starting from biaryl phosphates [52], biaryl phosphonates II [53-56], and triaryl phosphates [57-61] (Scheme 1d, path b). In search for alternative ways for the preparation of biaryls under photoinduced metal-free ecosustainable conditions we reinvestigated the photochemistry of di- and triaryl phosphates III and IV (Scheme 1e), compounds that can be easily achieved from the corresponding phenols $[62,63]$.

\section{Results and Discussion}

At the onset of our investigation, we tested a triaryl phosphate such as 4-chlorophenyl diphenyl phosphate (1a), as the model compound in different solvents by irradiation in a multilamp reactor (wavelength centered at $310 \mathrm{~nm}$, see Supporting Information File 1 for details). The obtained results are depicted in Table 1. Compound 1a $(0.02 \mathrm{M})$ was quite photostable in dichloromethane, acetonitrile, and acetone (Table 1, entries 1-3), whereas 4-chlorobiphenyl (2a) was observed in traces as the only product in neat methanol (30\% of 1a consumption, Table 1, entry 4). Interestingly, the addition of water (a methanol/water 2:1 mixture) increased the overall yield of the product 2a (up to 16\%) along with negligible amounts of biphenyl (2b). Decreasing the concentration of $1 \mathrm{a}$ (to $10^{-2} \mathrm{M}$ ) in the examined conditions was found noxious for the reaction course (Table 1, entry 6), but shifting the wavelength to $254 \mathrm{~nm}$ led to significant amounts of the desired biaryl (Table 1, entry 7). The yields started to be satisfactory, however, when performing the reaction at $310 \mathrm{~nm}$ using 2,2,2-trifluoroethanol (TFE) as the solvent ( $45 \%$ yield, entry 8 in Table 1$)$. We thus decided to replace part of the rather expensive and toxic solvent TFE with acetone (Table 1, entries 9-12) and the best results were obtained when using a TFE/acetone 4:1 mixture (Table 1, entry 10) with an 
Table 1: Optimization of the reaction conditions.

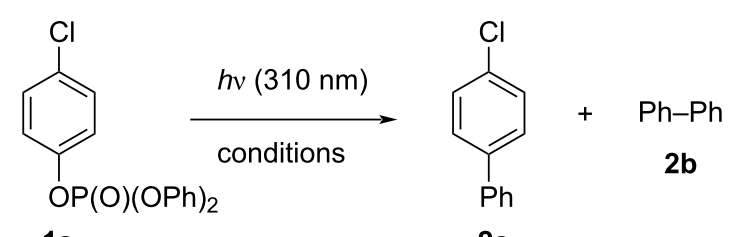

$1 \mathbf{a}$

$2 a$

\begin{tabular}{|c|c|c|c|}
\hline entry & reaction conditions & $\lambda_{\text {irr }}(\mathrm{nm})$ & products, yield (\%) \\
\hline 1 & $1 \mathrm{a}(0.02 \mathrm{M}), \mathrm{CH}_{2} \mathrm{Cl}_{2}$ & 310 & $-a$ \\
\hline 2 & 1a $(0.02 \mathrm{M}), \mathrm{CH}_{3} \mathrm{CN}$ & 310 & $-a$ \\
\hline 3 & $1 \mathrm{a}(0.02 \mathrm{M})$, acetone & 310 & $-\mathrm{a}$ \\
\hline 4 & $1 \mathrm{a}(0.02 \mathrm{M}), \mathrm{CH}_{3} \mathrm{OH}$ & 310 & $2 a, 3^{b}$ \\
\hline 5 & 1a $(0.02 \mathrm{M}), \mathrm{CH}_{3} \mathrm{OH} / \mathrm{H}_{2} \mathrm{O} 2: 1$ & 310 & $\mathbf{2 a}, 16 ; \mathbf{2 b}, 1$ \\
\hline 6 & $1 \mathrm{a}(0.01 \mathrm{M}), \mathrm{CH}_{3} \mathrm{OH} / \mathrm{H}_{2} \mathrm{O} 2: 1$ & 310 & $2 a, 6$ \\
\hline 7 & $1 \mathrm{a}(0.01 \mathrm{M}), \mathrm{CH}_{3} \mathrm{OH} / \mathrm{H}_{2} \mathrm{O} 2: 1$ & 254 & $2 a, 44$ \\
\hline 8 & $1 \mathrm{a}(0.02 \mathrm{M}), \mathrm{CF}_{3} \mathrm{CH}_{2} \mathrm{OH}$ & 310 & $2 \mathbf{a}, 45 ; \mathbf{2 b}, 2$ \\
\hline 9 & $1 \mathrm{a}(0.02 \mathrm{M}), \mathrm{CF}_{3} \mathrm{CH}_{2} \mathrm{OH} /$ acetone $9: 1$ & 310 & $2 a, 38 ; 2 b, 2$ \\
\hline 10 & 1a (0.02 M), $\mathrm{CF}_{3} \mathrm{CH}_{2} \mathrm{OH} /$ acetone $4: 1$ & 310 & $2 a, 67 ; 2 b, 4$ \\
\hline 11 & 1a $(0.02 \mathrm{M}), \mathrm{CF}_{3} \mathrm{CH}_{2} \mathrm{OH} /$ acetone $7: 3$ & 310 & $2 a, 48 ; 2 b, 3$ \\
\hline 12 & 1a $(0.02 \mathrm{M}), \mathrm{CF}_{3} \mathrm{CH}_{2} \mathrm{OH} /$ acetone $1: 1$ & 310 & $2 \mathbf{a}, 14 ; \mathbf{2 b}, 2$ \\
\hline 13 & 1a $(0.04 \mathrm{M}), \mathrm{CF}_{3} \mathrm{CH}_{2} \mathrm{OH} /$ acetone $4: 1$ & 310 & $2 a, 57 ; 2 b, 2$ \\
\hline 14 & 1a $(0.06 \mathrm{M}), \mathrm{CF}_{3} \mathrm{CH}_{2} \mathrm{OH} /$ acetone $4: 1$ & 310 & $\mathbf{2 a}, 67 ; \mathbf{2 b}, 12$ \\
\hline 15 & 1a $(0.02 \mathrm{M}), \mathrm{CF}_{3} \mathrm{CH}_{2} \mathrm{OH} /$ acetone $4: 1^{\mathrm{c}}$ & & $-\mathrm{a}$ \\
\hline
\end{tabular}

aNo consumption of $1 \mathrm{a}$ observed; ${ }^{\mathrm{b}} 30 \%$ consumption of $1 \mathrm{a}$ measured; cthe reaction mixture was stored in the dark for $24 \mathrm{~h}$.

isolated yield of $\mathbf{2 a}$ of $67 \%$ along with $\mathbf{2 b}$ ( $4 \%$ yield) as the byproduct. A further increase in the concentration of the substrate (Table 1, entries 13 and 14) resulted in a lowering of the selectivity (the undesired product $\mathbf{2 b}$ was detected in up to $12 \%$ yield). Finally, no reaction took place when the solution was covered by an aluminum foil and stored in the photochemical apparatus for $24 \mathrm{~h}$ (Table 1, entry 15).

Encouraged by the results collected in Table 1, in particular with the fact that the byproduct $\mathbf{2 b}$ was formed in such small amounts, we used the conditions described in entry 10 (Table 1) to explore the scope of the process by investigating other $n$-substituted phenyl diphenyl phosphates (1a-l, see Scheme 2). Thus, the irradiation of triphenyl phosphate (1b) gave the corresponding biphenyl (2b) in $67 \%$ yield. Similar results were obtained with 4-alkylphenyl diphenyl phosphates, that afforded the 4 -substituted biaryls $\mathbf{2 c - e}$ in up to $83 \%$ yield. However, when examining substrates bearing a strong electron-donating substituent ( $\mathrm{G}=4-\mathrm{OMe}, 4-\mathrm{OPh}, 3-\mathrm{OMe})$, the efficiency of the process decreased (see the yields of $\mathbf{2 f}, \mathbf{g}$, and $\mathbf{2 i}$ in Scheme 2). On the other hand, the presence of an electron-withdrawing group (e.g., 4-CN, compound $\mathbf{1 h}$ ) completely inhibited the reaction and $\mathbf{l} \mathbf{h}$ was recovered unaltered after the irradiation. Better results have been, however, obtained with polysubstituted de- rivatives $\mathbf{1} \mathbf{j}-\mathbf{l}$. In these cases, the expected phenylated arenes $\mathbf{2 j}-\mathbf{l}$ were isolated in the $50-64 \%$ range.

We were then intrigued to extend the scope of the reaction by focusing on a few ethyl diaryl phosphates 3a-e. Gratifyingly, the formation of the symmetric biaryls 4 took place efficiently with the substrates bearing strong electron-donating substituents, especially when present in the para-position (see the case of $4 \mathbf{a}-\mathbf{c})$. Unfortunately, the unsymmetric biaryl $4 \mathbf{e}$ was detected in a very poor amount.

To investigate the reaction mechanism, some photophysical parameters of compounds $\mathbf{1}$ and $\mathbf{3}$ were determined. All the phosphates examined were barely fluorescent in methanol, with an emission quantum yield $\left(\Phi_{\mathrm{em}}\right)$ in the $0.005-0.06$ range (see Table 2 and Supporting Information File 1 for further details).

We thus focused on compounds $\mathbf{1 e}, \mathbf{1 h}, \mathbf{3 a}$ and $\mathbf{3 c}$ as the model substrates. In the case of compounds $\mathbf{1 e}$ and $\mathbf{1 h}$, we observed that the fluorescence is significantly red shifted (about $30 \mathrm{~nm}$ ) with respect to that of the corresponding diethyl aryl phosphates (see Figure 1 and Figure 2). On the other hand, when focusing on compound 3a, we noticed the presence of two emission bands located at 307 and $360 \mathrm{~nm}$, respectively (see 


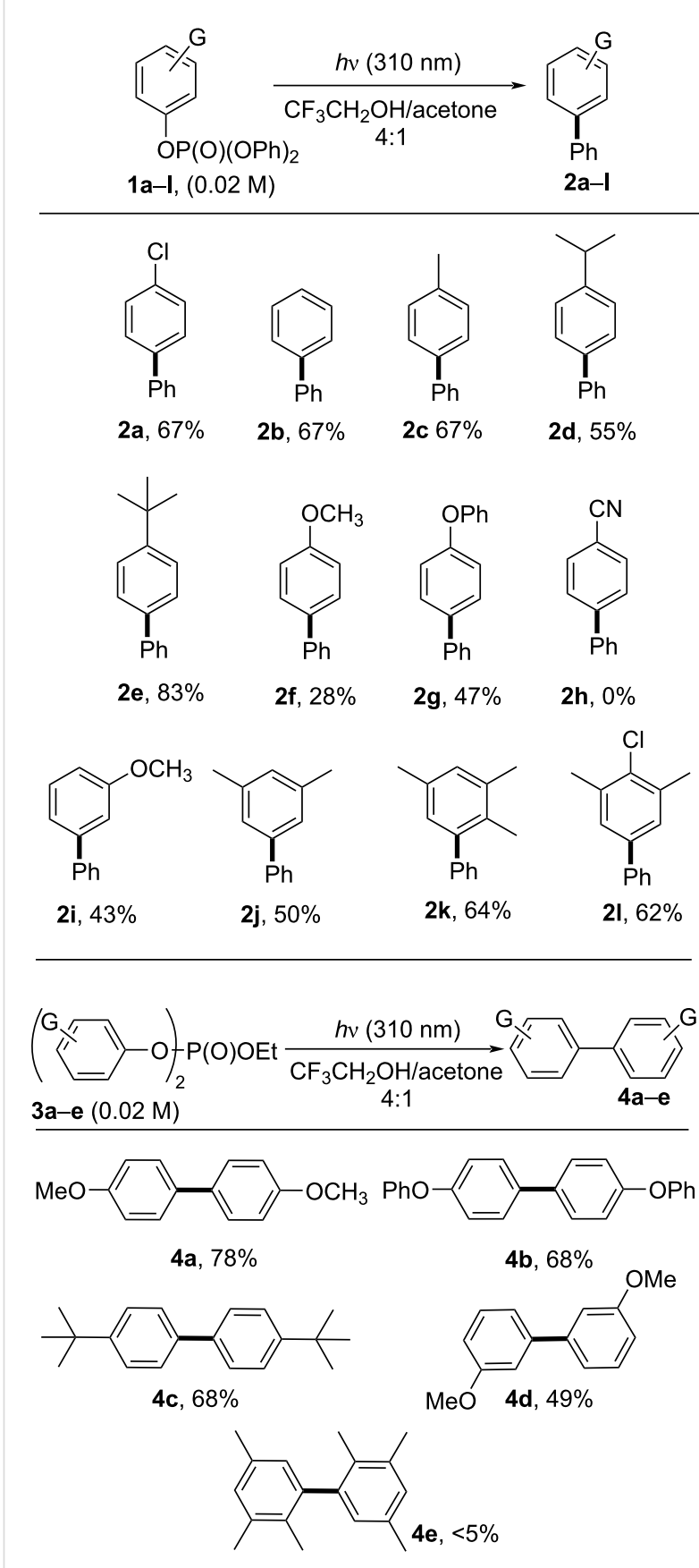

Scheme 2: Metal-free photochemical synthesis of biaryls 2 and $\mathbf{4}$.

Figure 3) and their relative intensity was solvent dependent. Indeed, the band at $360 \mathrm{~nm}$ is favored and slightly blue shifted when increasing the proticity of the medium (see the comparison of the fluorescence spectra obtained in methanol and in a methanol/TFE 4:1 mixture, Figure 3). A similar behavior was observed with compound $\mathbf{3 c}$, where a single emission band located at ca. $290 \mathrm{~nm}$ is observable in neat methanol, whereas the presence of TFE causes a lowering of that emission, in favor of a second band in the $330-350 \mathrm{~nm}$ region (Figure 4). These two
Table 2: Emission data of selected diaryl- and triaryl phosphates 1 and 3.

\begin{tabular}{lll} 
compound & $\lambda_{\mathrm{em}}(\mathrm{nm})$ & $\Phi_{\mathrm{em}}{ }^{\mathrm{a}}$ \\
\hline $\mathbf{1 a}$ & 300 & 0.005 \\
$\mathbf{1 b}$ & 315 & 0.017 \\
$\mathbf{1 e}$ & 319 & 0.025 \\
$\mathbf{1 f}$ & 312 & 0.059 \\
$\mathbf{1 h}$ & 335 & 0.023 \\
3a & 307,360 & 0.030 \\
3c & 294 & 0.062 \\
\hline
\end{tabular}

aMeasured by comparison with 4-chloroanisole $\left(\Phi_{\mathrm{F}}=0.019\right.$ in $\left.\mathrm{MeOH}\right)$ [64].

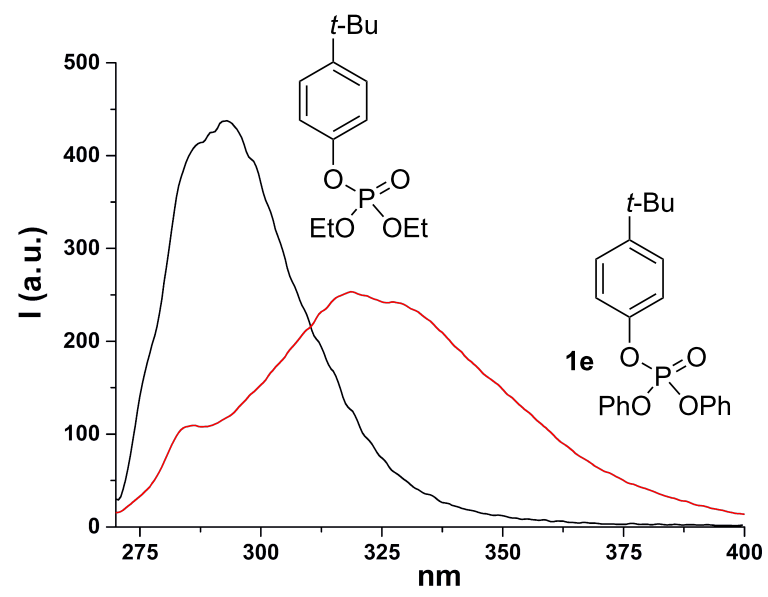

Figure 1: Emission spectrum of compound 1e (red) and of diethyl p-tert-butylphenyl phosphate (black) in methanol.

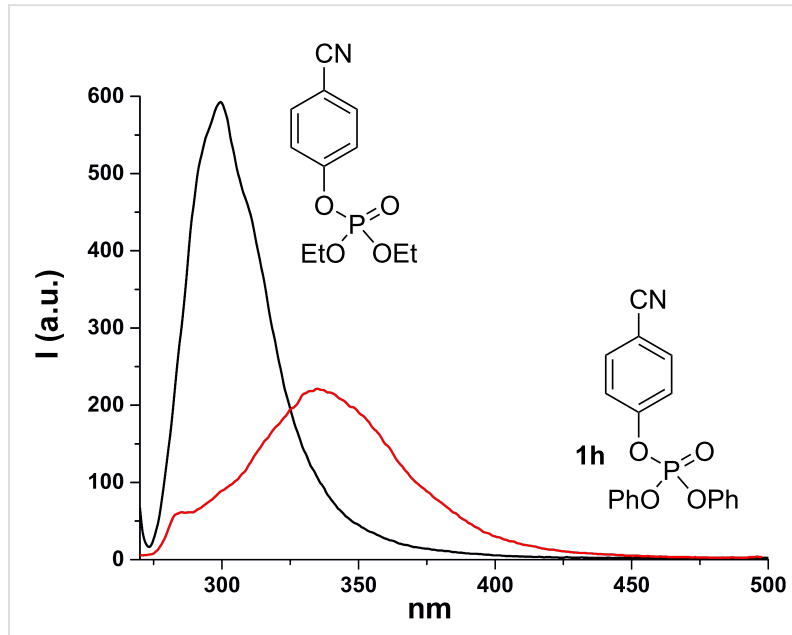

Figure 2: Emission spectrum of compound $\mathbf{1 h}$ (red) and of diethyl $p$-cyanophenyl phosphate (black) in methanol. 


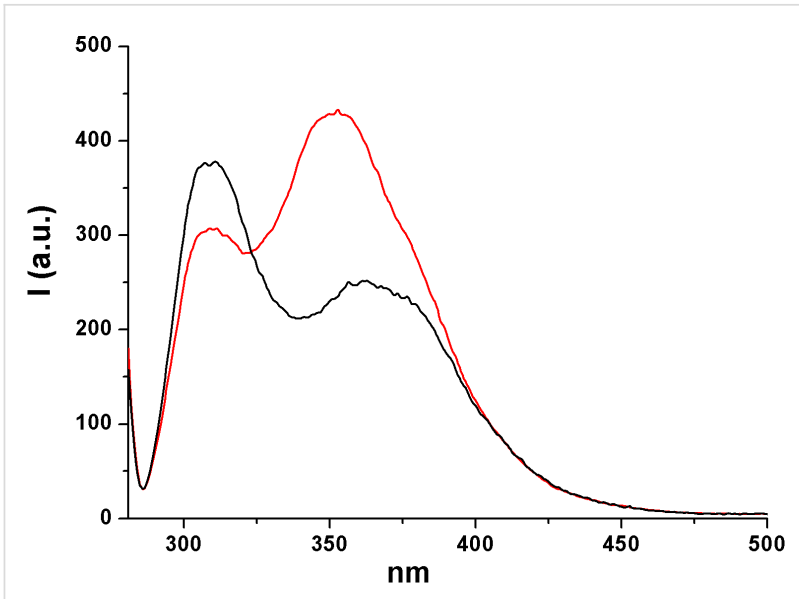

Figure 3: Emission spectrum of compound 3a in methanol (black) and in a methanol/TFE 4:1 mixture (red).

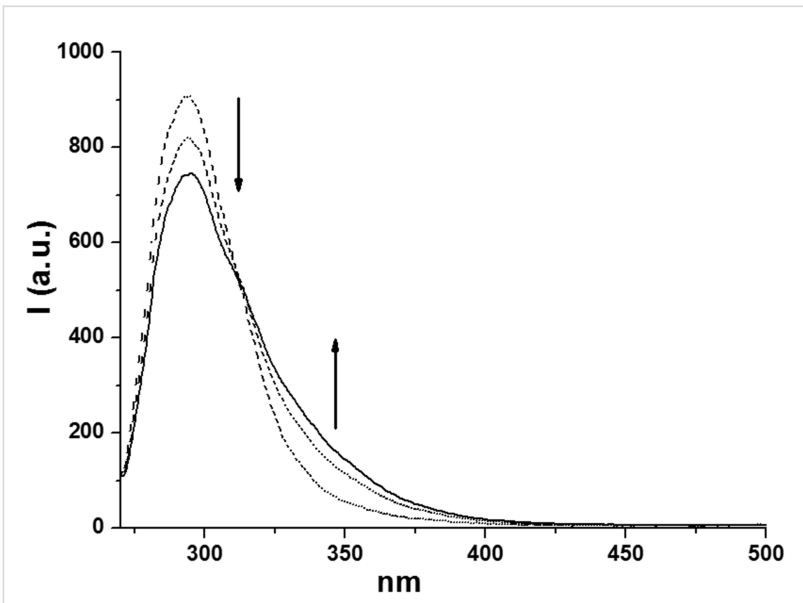

Figure 4: Emission spectrum of $3 \mathrm{c}$ in $\mathrm{MeOH}$ (dotted line) and in the presence of increasing amounts of TFE (up to $20 \% \mathrm{v} / \mathrm{v}$, continuous line).

emissions have been assigned, on the basis of our results and of the reported literature $[58,61]$, to the singlet monomeric excited state and to the exciplex, respectively.
While aryl phosphates have been only sparsely used as substrates in thermal cross-coupling reactions [65-67], their photochemical behavior has been the subject of various investigations in the last decades [28,29,64,68]. Simple (electron-rich) monoaryl phosphates are known to undergo the photoheterolysis of the Ar-O bond to form aryl cations [28,36]. The presence of an electron-withdrawing group (e.g., $\mathrm{NO}_{2}$ ) may, however, divert the reactivity since a photoinduced solvolysis occurred as demonstrated by Havinga more than 70 years ago [69]. In alternative, the irradiation of monoaryl phosphates in the presence of a strong nucleophile (e.g., a tin anion) led to an ipso substitution reaction via an $\mathrm{ArS}_{\mathrm{RN}} 1$ process [70].

The situation dramatically changes when a further aryl group is present in the phosphates since none of the above-mentioned processes took place. In fact, our investigations, in according with early works [52,71], suggested that both diaryl and triaryl phosphates are prone to generate an intramolecular exciplex $5^{*}$ under irradiation (Scheme 3, path (a)), on the route to the extrusion of the phosphate moiety. This is demonstrated by the formation of a new emission band when more than one aryl group is present in the aryl phosphate (see Figure 1). In our investigation, we likewise stated that the formation of $5^{*}$ (from $\mathbf{1}$ and $\mathbf{3}$ ) is highly favored in highly protic solvents such as TFE, as well evidenced, among the others, in the cases of $1 \mathbf{e}$ and $\mathbf{4 c}$, and as already reported in the formation of other intramolecular aromatic exciplexes [72].

The so generated exciplex apparently plays a key role in the formation of the biaryls $\mathbf{2}$ and $\mathbf{4}$ probably via the formation of the biradical intermediate 6 [55] preceding the loss of $\mathrm{ROP}(\mathrm{O})(\mathrm{OH})_{2}$ (paths (b), (c), Scheme 3). The long irradiation time required to achieve a complete consumption of the substrates $\mathbf{1}$ and $\mathbf{3}$ is in accordance with the low quantum yield values reported for this process $[58,61]$. Furthermore, a dependence on the nature of the aromatic substituents $G$ was apparent, since arylation took place (in variable yields) with electron-rich aromatic substituents, while it was completely in-

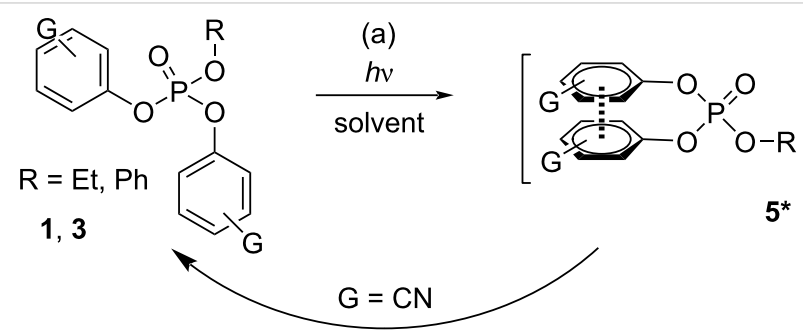

(b') (b)

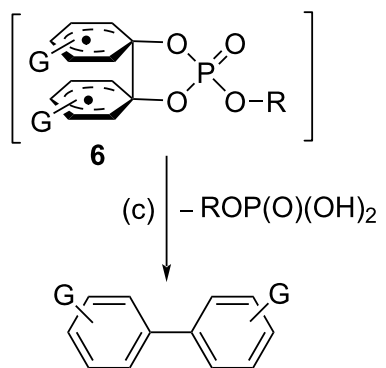

2,4 
hibited in the presence of electron-withdrawing groups (path (b'), in Scheme 3). In the case of the triaryl phosphates, biphenyl (1b) is formed as the byproduct in $<5 \%$ yield.

\section{Conclusion}

We demonstrated that biaryls can be smoothly prepared via the photoextrusion of diaryl- and triaryl phosphates in protic media with the concomitant release of a molecule of phosphoric acid monoester. The reaction takes place in moderate yields but under very mild conditions with no need of any (photo)catalyst or additive, despite the scope of the process is in part limited since the presence of at least one electron-withdrawing group on an aromatic ring completely suppressed the reaction.

\section{Supporting Information}

\section{Supporting Information File 1}

Experimental section, fluorescence, and ${ }^{1} \mathrm{H}$ and ${ }^{13} \mathrm{C}$ NMR spectra.

[https://www.beilstein-journals.org/bjoc/content/ supplementary/1860-5397-16-250-S1.pdf]

\section{Funding}

H. Q. thanks the Arab American University-Palestine (AAUP) for financial support, and the University of Pavia (Italy) for hosting.

\section{ORCID ${ }^{\circledR}$ iDs}

Hisham Qrareya - https://orcid.org/0000-0003-0909-3760

Stefano Protti - https://orcid.org/0000-0002-5313-5692

Maurizio Fagnoni - https://orcid.org/0000-0003-0247-7585

\section{Preprint}

A non-peer-reviewed version of this article has been previously published as a preprint: https://doi.org/10.3762/bxiv.2020.110.v1

\section{References}

1. Hajduk, P. J.; Bures, M.; Praestgaard, J.; Fesik, S. W. J. Med. Chem. 2000, 43, 3443-3447. doi:10.1021/jm000164q

2. Horton, D. A.; Bourne, G. T.; Smythe, M. L. Chem. Rev. 2003, 103, 893-930. doi:10.1021/cr020033s

3. Klekota, J.; Roth, F. P. Bioinformatics 2008, 24, 2518-2525. doi:10.1093/bioinformatics/btn479

4. Goa, K. L.; Wagstaff, A. J. Drugs 1996, 51, 820-845. doi:10.2165/00003495-199651050-00008

5. McElroy, W. T.; DeShong, P. Tetrahedron 2006, 62, 6945-6954. doi:10.1016/j.tet.2006.04.074

6. Torres, J. C.; Pinto, A. C.; Garden, S. J. Tetrahedron 2004, 60, 9889-9900. doi:10.1016/j.tet.2004.08.030
7. Bringmann, G.; Price Mortimer, A. J.; Keller, P. A.; Gresser, M. J.; Garner, J.; Breuning, M. Angew. Chem., Int. Ed. 2005, 44, 5384-5427. doi:10.1002/anie.200462661

8. Noyori, R.; Takaya, H. Acc. Chem. Res. 1990, 23, 345-350. doi:10.1021/ar00178a005

9. Wallace, T. W. Org. Biomol. Chem. 2006, 4, 3197-3210. doi:10.1039/b608470m

10. Berthod, M.; Mignani, G.; Woodward, G.; Lemaire, M. Chem. Rev. 2005, 105, 1801-1836. doi:10.1021/cr040652w

11. Vasconcelos, S. N. S.; Reis, J. S.; de Oliveira, I. M.; Balfour, M. N.; Stefani, H. A. Tetrahedron 2019, 75, 1865-1959. doi:10.1016/j.tet.2019.02.001

12. Nguyen, T. T. Org. Biomol. Chem. 2019, 17, 6952-6963. doi:10.1039/c9ob01304k

13. Felpin, F.-X.; Sengupta, S. Chem. Soc. Rev. 2019, 48, 1150-1193. doi:10.1039/c8cs00453f

14. Fanta, P. E. Chem. Rev. 1946, 38, 139-196. doi:10.1021/cr60119a004

15. Sambiagio, C.; Marsden, S. P.; Blacker, A. J.; McGowan, P. C. Chem. Soc. Rev. 2014, 43, 3525-3550. doi:10.1039/c3cs60289c

16. Amaya, T.; Jin, Y.; Tobisu, M. Tetrahedron Lett. 2019, 60, 151062. doi:10.1016/j.tetlet.2019.151062

17. de Meijere, A.; Diederich, F., Eds. Metal-Catalyzed Cross-Coupling Reactions, 2nd ed.; Wiley-VCH: Weinheim, Germany, 2004. doi:10.1002/9783527619535

18. Cepanec, I. Synthesis of biaryls; Elsevier: Oxford, U.K., 2004. doi:10.1016/b978-0-08-044412-3.x5000-3

19. Hussain, I.; Singh, T. Adv. Synth. Catal. 2014, 356, 1661-1696. doi:10.1002/adsc.201400178

20. García-López, J.-A.; Greaney, M. F. Chem. Soc. Rev. 2016, 45, 6766-6798. doi:10.1039/c6cs00220j

21. Hassan, J.; Sévignon, M.; Gozzi, C.; Schulz, E.; Lemaire, M. Chem. Rev. 2002, 102, 1359-1470. doi:10.1021/cr000664r

22. Nicolaou, K. C.; Bulger, P. G.; Sarlah, D. Angew. Chem., Int. Ed. 2005, 44, 4442-4489. doi:10.1002/anie.200500368

23. Hussain, I.; Capricho, J.; Yawer, M. A. Adv. Synth. Catal. 2016, 358, 3320-3349. doi:10.1002/adsc.201600354

24. Sun, C.-L.; Shi, Z.-J. Chem. Rev. 2014, 114, 9219-9280. doi:10.1021/cr400274j

25. Sun, C.-L.; Li, H.; Yu, D.-G.; Yu, M.; Zhou, X.; Lu, X.-Y.; Huang, K.; Zheng, S.-F.; Li, B.-J.; Shi, Z.-J. Nat. Chem. 2010, 2, 1044-1049. doi:10.1038/nchem.862

26. Sawama, Y.; Asai, S.; Kawajiri, T.; Monguchi, Y.; Sajiki, H. Chem. - Eur. J. 2015, 21, 2222-2229. doi:10.1002/chem.201405558

27. Guo, L.; Liu, F.; Wang, L.; Yuan, H.; Feng, L.; Kürti, L.; Gao, H. Org. Lett. 2019, 21, 2894-2898. doi:10.1021/acs.orglett.9b00927

28. Dichiarante, V.; Protti, S.; Fagnoni, M. J. Photochem. Photobiol., A 2017, 339, 103-113. doi:10.1016/j.jphotochem.2017.02.007

29. Lazzaroni, S.; Ravelli, D.; Protti, S.; Fagnoni, M.; Albini, A. C. R. Chim. 2017, 20, 261-271. doi:10.1016/j.crci.2015.11.024

30. Hofmann, J.; Heinrich, M. R. Tetrahedron Lett. 2016, 57, 4334-4340. doi:10.1016/j.tetlet.2016.08.034

31. Ghosh, I.; Marzo, L.; Das, A.; Shaikh, R.; König, B. Acc. Chem. Res. 2016, 49, 1566-1577. doi:10.1021/acs.accounts.6b00229

32. Milanesi, S.; Fagnoni, M.; Albini, A. Chem. Commun. 2003, 216-217. doi:10.1039/b210243a

33. Barragan, E.; Poyil, A. N.; Yang, C.-H.; Wang, H.; Bugarin, A. Org. Chem. Front. 2019, 6, 152-161. doi:10.1039/c8qo00938d

34. Fagnoni, M.; Mella, M.; Albini, A. Org. Lett. 1999, 1, 1299-1301. doi:10.1021/ol990982g 
35. Dichiarante, V.; Fagnoni, M.; Albini, A. Angew. Chem., Int. Ed. 2007, 46, 6495-6498. doi:10.1002/anie.200701462

36. De Carolis, M.; Protti, S.; Fagnoni, M.; Albini, A. Angew. Chem., Int. Ed. 2005, 44, 1232-1236. doi:10.1002/anie.200461444

37. Qrareya, H.; Protti, S.; Fagnoni, M. J. Org. Chem. 2014, 79, 11527-11533. doi:10.1021/jo502172c

38. Crespi, S.; Protti, S.; Fagnoni, M. J. Org. Chem. 2016, 81, 9612-9619. doi:10.1021/acs.joc.6b01619

39. da Silva Júnior, P. E.; Amin, H. I. M.; Nauth, A. M.; da Silva Emery, F.; Protti, S.; Opatz, T. ChemPhotoChem 2018, 2, 878-883. doi:10.1002/cptc.201800125

40. Qiu, D.; Lian, C.; Mao, J.; Fagnoni, M.; Protti, S. J. Org. Chem. 2020, 85, 12813-12822. doi:10.1021/acs.joc.0c01895

41. Motherwell, W. B.; Pennell, A. M. K. J. Chem. Soc., Chem. Commun. 1991, 877-879. doi:10.1039/c39910000877

42. da Mata, M. L. E. N.; Motherwell, W. B.; Ujjainwalla, F. Tetrahedron Lett. 1997, 38, 137-140. doi:10.1016/s0040-4039(96)02236-8

43. da Mata, M. L. E. N.; Motherwell, W. B.; Ujjainwalla, F. Tetrahedron Lett. 1997, 38, 141-144. doi:10.1016/s0040-4039(96)02237-x

44. Holden, C. M.; Sohel, S. M. A.; Greaney, M. F. Angew. Chem., Int. Ed. 2016, 55, 2450-2453. doi:10.1002/anie.201510236

45. Rasheed, O. K.; Hardcastle, I. R.; Raftery, J.; Quayle, P. Org. Biomol. Chem. 2015, 13, 8048-8052. doi:10.1039/c5ob01239b

46. Yanagi, T.; Nogi, K.; Yorimitsu, H. Chem. - Eur. J. 2020, 26, 783-787. doi:10.1002/chem.201903570

47. Yanagi, T.; Otsuka, S.; Kasuga, Y.; Fujimoto, K.; Murakami, K.; Nogi, K.; Yorimitsu, H.; Osuka, A. J. Am. Chem. Soc. 2016, 138, 14582-14585. doi:10.1021/jacs.6b10278

48. Morioka, T.; Nishizawa, A.; Furukawa, T.; Tobisu, M.; Chatani, N. J. Am. Chem. Soc. 2017, 139, 1416-1419. doi:10.1021/jacs.6b12293

49. Somerville, R. J.; Martin, R. Angew. Chem., Int. Ed. 2017, 56, 6708-6710. doi:10.1002/anie.201702188

50. Takahashi, F.; Nogi, K.; Yorimitsu, H. Org. Lett. 2018, 20, 6601-6605. doi:10.1021/acs.orglett.8b02972

51. Kloss, F.; Neuwirth, T.; Haensch, V. G.; Hertweck, C. Angew. Chem., Int. Ed. 2018, 57, 14476-14481. doi:10.1002/anie.201805961

52. Okamoto, Y.; Nakamura, M.; And, M. S.; Takamuku, S. Photochem. Photobiol. 1992, 56, 403-407. doi:10.1111/j.1751-1097.1992.tb02178.x

53. Shi, M.; Okamoto, Y.; Takamuku, S. Tetrahedron Lett. 1991, 32 , 6899-6902. doi:10.1016/0040-4039(91)80438-c

54. Nakamura, M.; Sawasaki, K.; Okamoto, Y.; Takamuku, S. J. Chem. Soc., Perkin Trans. 1 1994, 141-146. doi:10.1039/p19940000141

55. Nakamura, M.; Shi, M.; Okamoto, Y.; Takamuku, S. J. Photochem. Photobiol., A 1995, 85, 111-118. doi:10.1016/1010-6030(94)03894-z

56. Okamoto, Y.; Tatsuno, T.; Takamuku, S. Phosphorus, Sulfur Silicon Relat. Elem. 1996, 117, 129-138. doi:10.1080/10426509608038780

57. Finnegan, R. A.; Matson, J. A. J. Am. Chem. Soc. 1972, 94, 4780-4782. doi:10.1021/ja00768a084

58. Shi, M.; Yamamoto, K.; Okamoto, Y.; Takamuku, S. Phosphorus, Sulfur Silicon Relat. Elem. 1991, 60, 1-14. doi:10.1080/10426509108233919

59. Nakamura, M.; Sawasaki, K.; Okamoto, Y.; Takamuku, S. Bull. Chem. Soc. Jpn. 1995, 68, 3189-3197. doi:10.1246/bcsj.68.3189
60. Nakamura, M.; Okamoto, Y.; Takamuku, S. Phosphorus, Sulfur Silicon Relat. Elem. 1995, 106, 137-144. doi:10.1080/10426509508027899

61. Okamoto, Y.; Tatsuno, T.; Takamuku, S. Heteroat. Chem. 1996, 7, 257-261.

doi:10.1002/(sici)1098-1071(199608)7:4<257::aid-hc7>3.0.co;2-2

62. Genkina, G. K.; Shipov, A. E.; Mastryukova, T. A.; Kabachnik, M. I. Russ. J. Gen. Chem. 1996, 66, 1742-1744.

63. Bruice, T. C.; Blaskó, A.; Petyak, M. E. J. Am. Chem. Soc. 1995, 117, 12064-12069. doi:10.1021/ja00154a005

64. Dichiarante, V.; Dondi, D.; Protti, S.; Fagnoni, M.; Albini, A. J. Am. Chem. Soc. 2007, 129, 5605-5611. doi:10.1021/ja068647s

65. Protti, S.; Fagnoni, M. Chem. Commun. 2008, 3611-3621. doi:10.1039/b801888j

66. Chen, X.; Chen, Z.; So, C. M. J. Org. Chem. 2019, 84, 6337-6346. doi:10.1021/acs.joc.9b00669

67. Chen, Z.; Chen, X.; So, C. M. J. Org. Chem. 2019, 84, 6366-6376. doi:10.1021/acs.joc.9b00703

68. Ravelli, D.; Fagnoni, M. Photochemistry of Phosphate and Sulfonate Esters. In CRC Handbook of Organic Photochemistry and Photobiology, 3rd ed.; Griesbeck, A.; Oelgemoeller, M.; Ghetti, F., Eds.; CRC Press: Boca Raton, FL, USA, 2012; pp 393-417.

69. Cornelisse, J.; Havinga, E. Chem. Rev. 1975, 75, 353-388. doi:10.1021/cr60296a001

70. Chopa, A. B.; Silbestri, G. F.; Lockhart, M. T. J. Organomet. Chem. 2005, 690, 3865-3877. doi:10.1016/j.jorganchem.2005.05.023

71. Naito, I.; Kinoshita, A.; Okamoto, Y.; Takamuku, S. ACS Symp. Ser. 1995, 579, 139-150. doi:10.1021/bk-1994-0579.ch011

72. Siqintuya; Sueishi, Y.; Yamamoto, S. J. Photochem. Photobiol., A 2007, 186, 41-46. doi:10.1016/j.jphotochem.2006.07.010

\section{License and Terms}

This is an Open Access article under the terms of the Creative Commons Attribution License (https://creativecommons.org/licenses/by/4.0). Please note that the reuse, redistribution and reproduction in particular requires that the author(s) and source are credited and that individual graphics may be subject to special legal provisions.

The license is subject to the Beilstein Journal of Organic Chemistry terms and conditions:

(https://www.beilstein-journals.org/bjoc/terms)

The definitive version of this article is the electronic one which can be found at: https://doi.org/10.3762/bjoc. 16.250 